\title{
Klasifikasi Diagnosa Dalam Keperawatan
}

\author{
Shela Junita Putri
}

Shelajunita01@gmail.com

\section{Latar Belakang}

Diagnosa keperawatan adalah suatu pernyataan yang menjelaskan respons manusia (status kesehatan atau resiko perubahan pola) dari individu atau kelompok dimana perawat secara akuntabilitas dapat mengidentifikasi dan memberikan intervensi secara pasti untuk menjaga status kesehatan menurunkan, membatasi, mencegah, dan merubah. Sebagai suatu aspek yang terpenting dalam proses keperawatan, perumusan diagnosa keperawatan ini sangatlah vital untuk dilakukan. Pernahkan kita mendengar beberapa diagnosa keperawatan pada pasien.

Diagnosis Keperawatan merupakan keputusan klinik tentang respon individu, keluarga dan masyarakat tentang masalah kesehatan aktual atau potensial, dimana berdasarkan pendidikan dan pengalamannya, perawat secara akontabilitas dapat mengidentifikasi dan memberikan intervensi secara pasti untuk menjaga, menurunkan, membatasi, mencegah dan merubah status kesehatan klien Diagnosa keperawatan ditetapkan berdasarkan analisis dan interpretasi data yang diperoleh dari pengkajian keperawatan klien. Diagnosa keperawatan memberikan gambaran tentang masalah atau status kesehatan klien yang nyata (aktual) dan kemungkinan akan terjadi, dimana pemecahannya dapat dilakukan dalam batas wewenang perawat.

Proses keperawatan telah diidentfikasikan sebagai metoda ilmiah keperawatan untuk para penerima tindakan keperawatan. Kebanyakan sekolah-sekolah keperawatan sekarang memasukkan proses keperawatan sebagai sautu komponen dari konsep kerja konsepatual mereka. Tujuan Mengidentifikasi prioritas keperawatan, mengarahkan intervensi keperawatan untuk memenuhi kebutuhan yang memiliki prioritas tinggi, memberikan bahasa umum dan membentuk dasar untuk 
komunikasi dan pemahaman antara profesional keperawatan dan tim layanan kesehatan.

Diagnosa keperawatan berfokus - masalah mengandung batasan karakteristik dan faktor yang berhubungan . diagnosa promosi kesehatan umumnya hanya batasan karakteristik, meskipun faktor yang berhubungan dapat digunakan jika dapat meningkatkan pemahaman diagnosa. Perawat mendiagnosis masalah kesehatan, menyatakan risiko, dan kesiapan promosi kesehatan. Diagnosis berfokus masalah tidak boleh dipandang lebih penting dari pada diagnosis risiko. Kadang-kadang diagnosis risiko dapat menjadi diagnosis dengan prioritas tertinggi bagi pasien.

Diagnosa keperawatan ditetapkan berdasarkan analisis dan interpretasi data yang diperoleh dari pengkajian keperawatan klien. Diagnosa keperawatan memberikan gambaran tentang masalah atau status kesehatan klien yang nyata (aktual) dan kemungkinan akan terjadi, dimana pemecahannya dapat dilakukan dalam batas wewenang perawat. Diagnosa keperawatan berfokus - masalah mengandung batasan karakteristik dan faktor yang berhubungan.

\section{Metode}

Metode yang digunakan adalah metode literatur yaitu dengan mengambil data-data melalui buku-buku, situs-situs internet, E-book, jurnal yang terkait dalam penelitian tentang Klasifikasi Diagnosa Dalam Keperawatan.

Adapun Jurnal yang digunakan dalam penelitian ini dalam kurun waktu diatas tahun 2012 dengan mengambil referensi terkait dengan Klasifikasi Diagnosa Dalam Keperawatan.

\section{Hasil dan Pembahasan}

\section{Hasil}

Kualitas pengisian dokumentasi keperawatan dapat terlaksana dengan baik apabila fungsi manajerial atau kepemimpinan seorang kepala ruangan maupun ketua tim dalam pendampingan serta melakukan monitoring evaluasi terhadap perawat 
pelaksana dalam pengisian dokumentasi keperawatan. keberhasilan dalam pelaksanaan hubungan professional .khususnya metode tim serta peningkatan kualitas pelayanan asuhan keperawatan ditentukan dari dua hal yaitu kepemimpinan dan komunikasi efektif. Kepemimpinan dan komunikasi efektif yang dilakukan oleh perawat professional bertugas mengkoordinir, memberikan pengarahan kepada perawat pelaksana di timnya dalam pemberian asuhan keperawatan, maka memungkinkan pelayanan keperawatan dirasakan lebih baik, sehingga terwujudnya hubungan baik antara perawat dengan perawat, perawat dengan tim kesehatan lainnya dan perawat dengan pasien serta kepuasan perawat maupun pasien akan meningkat.

Masih banyak perawat yang belum mengetahui standar dalam klasifikasi dokumentasi Maka dari itu peran pendampingan dalam melatih perawat dalam hal pengisian dokumentasi keperawatan sehingga dapat meningkatkan pengetahuan serta kualitas perawat dalam pengisian dokumentasi keperawatan Hal tersebut didukung dari beberapa studi yang menunjukkan bahwa sebagian besar perawat di rumah sakit mereka tidak pernah belajar tentang klasifikasi dokumentasi. Bahwa responden dengan pendidikan S1 keperawatan t memiliki tingkat pengetahuan yang baik tentang asuhan keperawatan dengan Klasifikasi dokumentasi dibandingkan dengan responden degnan pendidikan D III Keperawatan.

Semakin tinggi pendidikan seseorang, semakin mudah orang tersebut menerima informasi, dan semakin banyak pula pengetahuan yang didapat tentang kesehatan. Pengetahuan sangat erat kaitannya dengan pendidikan maka seseorang dengan pendidikan tinggi, diharapkan orang tersebut semakin luas pengetahuannya. Begitupula jika melihat tingkatan tersebut, maka peneliti dapat menyimpulkan bahwa semakin tinggi pengetahuan perawat, maka semakin tinggi pula kemampuannya untuk melaksanakan pengisian dokumentasi asuhan keperawatan secara baik dan berkualitas. ada hubungan antara kualitas dokumentasi asuhan keperawatan dengan pelatihan, kualitas dokumentasi akan meningkat pada perawat yang pernah pelatihan dibanding yang belum pernah pelatihan 


\section{Pembahasan}

Kemampuan perawat dalam pengisian dokumentasi keperawatan yang berkualitas yaitu pengetahuan perawat terhadap pelaksanaan standard kualitas pengisian dokumentasi. Menurut pendapat peneliti dalam hal yang diberikan berupa pelatihan Standard dapat meningkatkan kemampuan perawat dalam pembuatan standar asuhan keperawatan serta pengetahuan perawat. Semakin tinggi tingkat pengetahuan perawat, maka semakin mempengaruhi cara pandang perawat, sehingga dapat mempengaruhi perilakunya yang akan berdampak terhadap kemampuannya dalam pengisian dokumentasi keperawatan yang berkualitas.

Dalam meningkatkan kualitas dokumentasi keperawatan yang dilakukan oleh perawat. Pentingnya pelatihan pendokumentasian bagi perawat memberikan dampak positif terhadap kinerja perawat khususnya dalam melakukan pendokumentasian asuhan kualitas keperawatan. Dampak positif penerapan Standar kualitas pendokumentasian dapat meningkatkan kualitas perawat dalam pengisian dokumentasi keperawatan. Hal ini menjadi bahan pertimbangan manajemen rumah sakit dalam melakukan pelatihan secara periodik kepada seluruh perawat ruangan, sehingga seluruh perawat dapat melakukan pengisisan dokumentasi dengan keseragaman bahasa yang sam dan terstandarkan, sehingga asuhan keperawatan yang diberikan dapat dirasakan oleh masyarakat berkualitas.

Diagnosa keperawatan menjadi dasar untuk pemilihan tindakan keperawatan untuk mencapai hasil bagi anda, sebagai perawat. Diagnosa keperawatan berfokus pada, respon aktual atau potensial klien terhadap masalah kesehatan dibandingkan dengan kejadian fisiologis, komplikasi, atau penyakit. Dalam pendokumentasian proses keperawatan merupakan salah satu bentuk penggunaan standar kualitas dalam pendokumentasian.

Perawat diharapkan memiliki rentang perhatian yang luas, baik pada klien sakit maupun sehat. Respons-respons tersebut merupakan reaksi terhadap masalah kesehatan dan proses kehidupan yang dialami klien. Masalah-masalah mengacu 
kepada proses respons klien terhdap kondisi sehat-sakit, sedangkan proses kehidupan mengacu pada respons klien terhadap kondisi yang terjadi selama rentang kehidupannya dimulai dari fase pembuahan hingga menjelang ajal dan meninggal yang mebutuhkan diagnosis keperawatan dan dapat diatasi atau diubah dengan intervensi keperawatan.

Diagnosis keperawatan risiko berhubungan dengan masalah dan memerlukan asuhan keperawatan untuk mencegah terjadinya masalah actual atau penurunan status kesehatan klien. Diagnosis keperawatan potensial berhubungan dengan masalah yang memerlukan data tambahan pengawasan dan pengamatan untuk membuktikan pengembangan masalah.

Pengalaman menunjukkan bahwa sering sekali perawat kesulitan dalam menentukan diagnosis keperawatan spesifik yang dialami oleh pasien.Hal ini mungkin karena pengkajian keperawatan yang tidak terstruktur dengan baik. Pengalaman menunjukkan bahwa pengkajian yang dilakukan oleh perawat tidak mempunyai urutan yang runut dan terkait dengan diagnosis keperawatan.Sering terjadi perawat mempunyai data tertentu tetapi kebingungan untuk menentukan data tersebut mendukung diagnosa keperawatan yang mana. Atau sebaliknya perawat mempunyai prediksi pasien mempunyai diagnosa tertentu tetapi tidak tahu data apa yang perlu dikaji untuk mendukung diagnosa tersebut muncul.

Luasnya area keperawatan dan banyaknya institusi pendidikan serta tempat pelayanan keperawatan di Indonesia maupun luar negeri, maka akan membutuhkan suatu sistem klasifikasi bahasa keperawatan yang terstandar untuk merumuskan diagnosis keperawatan, tujuan keperawatan dalam memberikan asuhan keperawatan. Proses kualitas dokumentasi terhadap tindakan yang dilakukan oleh perawat harus ditulis sebagai bukti terhadap segala tindakan yang dilakukan oleh perawat kepada pasien. Proses ini membantu perawat dalam melakukan asuhan keperawatan yang memerlukan ketelitian dan tanggung jawab tinggi, selain itu proses dokumentasi 
membantu menunjukan kesalahan atau kebenaran suatu tindakan yang telah dilakukan

Peningkatan mutu keperawatan dapat diperoleh jika perawat mampu melaksanakan kualitas pendokumentasian keperawatan sesuai standar, yaitu mulai dari pengkajian sampai dengan evaluasi lengkap dengan dokumentasi. Permasalahan yang sering muncul dan dihadapi di Indonesia dalam pelaksanaan asuhan keperawatan adalah banyak perawat yang belum melakukan pelayanan keperawatan sesuai standar asuhan keperawatan dan tidak disertai dokumentasi yang lengkap

Pentingnya pelatihan pendokumentasian bagi perawat memberikan dampak positif terhadap kinerja perawat khususnya dalam melakukan pendokumentasian asuhan keperawatan. Dampak positif penerapan Standar penignkatan kualitas dokumentasian dapat meningkatkan kualitas perawat dalam pengisian dokumentasi keperawatan.

\section{Penutup}

Dalam meningkatkan kualitas dokumentasi keperawatan yang dilakukan oleh perawat. Pentingnya pelatihan pendokumentasian bagi perawat memberikan dampak positif terhadap kinerja perawat khususnya dalam melakukan pendokumentasian asuhan kualitas keperawatan. Proses kualitas dokumentasi terhadap tindakan yang dilakukan oleh perawat harus ditulis sebagai bukti terhadap segala tindakan yang dilakukan oleh perawat kepada pasien. Proses ini membantu perawat dalam melakukan asuhan keperawatan yang memerlukan ketelitian dan tanggung jawab tinggi. 


\section{Daftar pustaka}

Made, E., Aprilia, N. (2017). PENGEMBANGAN FORMAT DOKUMENTASI ASUHAN KEPERAWATAN BERBASIS STANDARDIZED NURSING LANGUAGE (SNL) NANDA-I, NOC DAN NIC DI RUANG RAWAT INAP. Mahakam Nursing Journal. 2(2), 50-61.

Rahayu1, C., D., Mulyani, S. (2020). Pengambilan Keputusan Klinis Perawat. Jurnal Ilmiah Kesehatan, 1(1), 1-11.

Mohamad, A, E., Retno, P. (2012). PERBEDAAN TINGKAT KUALITAS DOKUMENTASI PROSES KEPERAWATAN SEBELUM DAN SESUDAH PENERAPAN NANDA-I, NIC, DAN NOC. Jurnal keperawaran soedirman. 7(2), 67-77.

Yana, H., Aria, P. (2019). Standar nursing language berbasis NANDA, NOC, dan NIC terhadap kualitas pengisian dokumentasi keperawatan. Jurnal Penelitian dan pemikiran Ilmiah Keperawatan. 5(2), 26-31.

Farida, N. (2016). RANCANG BANGUN SISTEM INFORMASI DIAGNOSA KEPERAWATAN AKTUAL PADA PENDERITA DIABETES MELITUS. Jurnal teknologi informasi. XI(31), 1-7.

Nur Aini. 2018. Teori Model Keperawatan. Malang, Universitas Muhammadiyah Malang.

Nurarif, Amin Huda dan Hardhi Kusuma. 2013. Aplikasi NANDA NIC NOC. Yogyakarta : Media Action Publishing.

Rofi, M., Warsito., B., E., Santoso., A., dkk. (2018). Diagnosa Keperawatan Yang Sering Ditegakkan Perawat Pada Pasien Tuberkulosis Paru di Rumah Sakit. Jurnal Kepemimpinan Dan Manajemen Keperawatan. 1(2), 2-8. 
Tokan, P., K., Sekunda, M., S. (2020). Penerapan Format Baru Pendokumentasian Asuhan Keperawatan di Poli Rawat Jalan Puskesmas. Jurnal Kesehatan Primer. 5(1), 61-69.

Supratti, Ashriady. (2016). Pendokumentasian Standar Asuhan Keperawatan Di Rumah Sakit Umum Daerah Mamuju, Indonesia. Jurnal Kesehatan MANARANG. 2(1), 44-51.

Simamora, R. H., Bukit, E., Purba, J. M., \& Siahaan, J. (2017). Penguatan kinerja perawat dalam pemberian asuhan keperawatan melalui pelatihan ronde keperawatan di rumah sakit royal prima medan. Jurnal pengabdian kepada masyarakat, 23(2), 300304.

Simamora, R. H. (2019). Socialization of Information Technology Utilization and Knowledge of Information System Effectiveness at Hospital Nurses in Medan, North Sumatra. Editorial Preface From the Desk of Managing Editor..., 10(9). 